\title{
Photographic Observation of Clouds by Aircraft during Snowfall Period in Hokuriku District
}

\author{
By Tomio Asai \\ Meteorological Research Institute \\ (Manuscript received 2 April 1964)
}

\begin{abstract}
The photographic observation by aircraft was performed on 20 January 1963 as a part of research project of heavy snowfall in Hokuriku District where is located in the central part of the Japan Sea coastal region of the Japan Islands. The horizontal distribution and the topography of clouds over the Japan Sea near Hokuriku District were obtained by making use of the aerial photographs taken from the aircraft at about 8 kilometers level in the way based on the usual aerial photogrammetry.

The cloud photographs show a characterisitic pattern changing from scattered cumulus clouds smaller than 1 kilometer in both horizontal and vertical dimensions in the west of the observation area to larger cumulus and cumulonimbus clouds reaching 3 kilometers level in the east where is covered with upper stratiform clouds. It is suggested that cumulus clouds seem to originate over the Japan Sea at least 200 to $300 \mathrm{~km}$ off the coast of Hokuriku District and a fairly amount of snow may be released efficiently just in Hokuriku District from the clouds containing sufficient water substance.
\end{abstract}

\section{Introduction}

It is well known fact that a great deal of snow falls in the Japan Sea coastal region of the Japan Islands usually called "Back Japan" in winter. Especially the amount of snowfall is remarkable in Hokuriku District located in the central part of Back Japan. Therefore, the study of the snowfall has been made by many authors. Most of general climatic features have been explained qualitatively by both effects of airmass modification due to the supply of sensible heat and moisture from the Japan Sea and of the obstacle of the Japan Islands to northwest monsoon. The former leads monsoon airmass to unstable stratification and the latter gives rise to ascending motion. They are insufficient, however, to explain local heavy snowfall particularly on the sea off and on the coastal plain in Hokuriku District observed occasionally. Some authors indicated the role of the local front found along near the coast which becomes active through the intensification or the formation of cyclone over the Japan Sea. Recently it was found that many cases of heavy snowfall were associated with the remarkable cold trough or cold vortex extending to the south part of the Japan Sea in the mid-troposphere. Furthermore, the important role of the extraordinary warm Tsushima Current in the Japan Sea running off the coast of Back Japan has been noticed by some investigators. Anyhow, it should become à serious blank to be filled at present that meteorological observations have scarcely been made over the Japan Sea.

In order to add some informations on the heavy snowfall and to find a clue to its mechanism, the heavy snowfall research project was established in 1962 . The present photographic observation by aircraft was a part of the first year series of observations which were carried out during 10 days from 16 to 25 January 1963 . Luckily or unluckily we encountered just the heaviest snowfall in recent years which had serious influence on the human life and social activity in Back Japan. All parts of the data obtained were arranged and published in a report on the collective data (1963).

The present paper describes some features 
of the cloud distribution over the Japan Sea near Hokuriku District obtained by the photographic observation from aircraft. The implications on the formation of cumulus clouds and the heavy snowfall in Hokuriku District are also provided.

\section{Observational procedure}

The photographic observation was made from an aircraft on 20 January 1963. The aircraft which left Nagoya airport (Komaki) at $10.42 \mathrm{JST}$, reached $7,500 \mathrm{~m}$ level before Komatsu. After then the level flight was kept at a true air speed of $97 \mathrm{~m} \mathrm{sec}^{-1}$ with a constant true air heading between the adja- cent points prescribed successively. The flight path and the arrival time at each corner point are shown in Fig. 1.

The aircraft available for the observation was one of Aerocommander $680 \mathrm{~F}$ type designed for the aerial photogrammetry. An aerial camera of $\mathrm{RC}-8$ type for the exclusive use in aircraft was mounted as its optical axis was vertical. The focal length and the view angle of the camera were $152.18 \mathrm{~mm}$ and $93^{\circ}$, respectively. The film size was of $230 \mathrm{~mm}$ square. A clock, an altimeter and a levelling instrument were inserted in one side of the field of view and photographed simultaneously for the reference data in the analyses. Orange

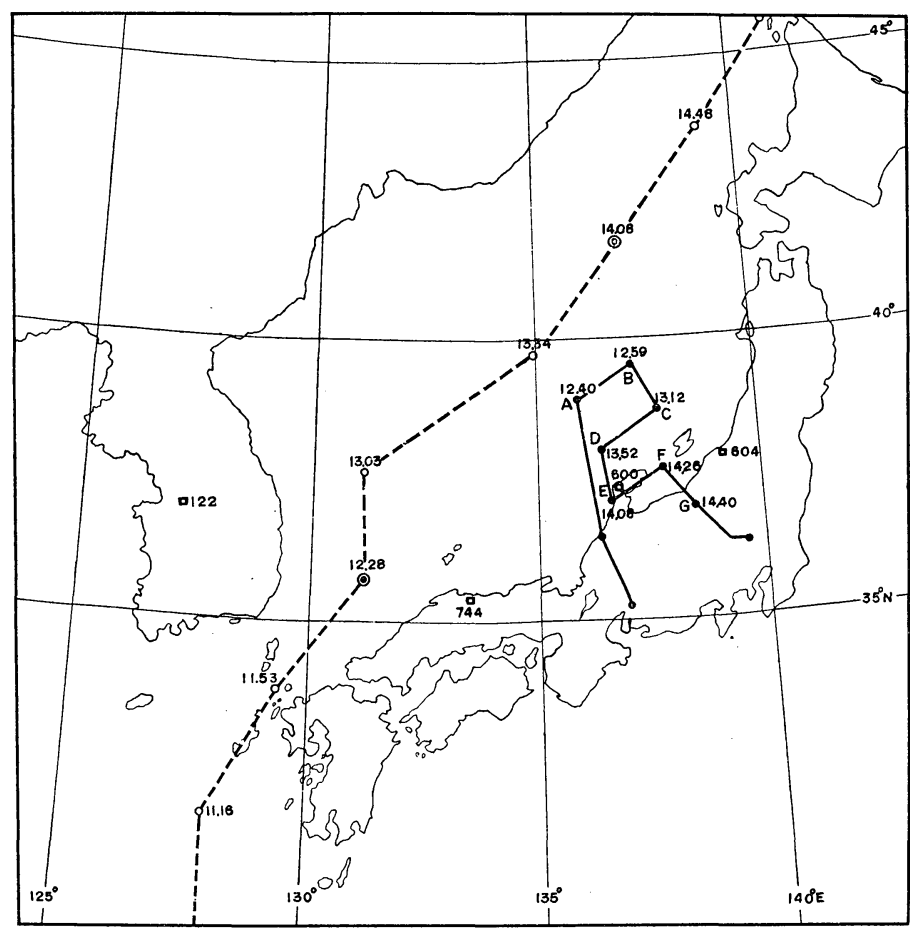

Fig. 1. (a) The flight path of photographic observation is shown by solid line on which the arrival time at each corner point is labeled in JST. Broken line is the path of RECCO Flight by U.S. Air Force. Squares denote radiosonde observation stations used in Fig. 3.

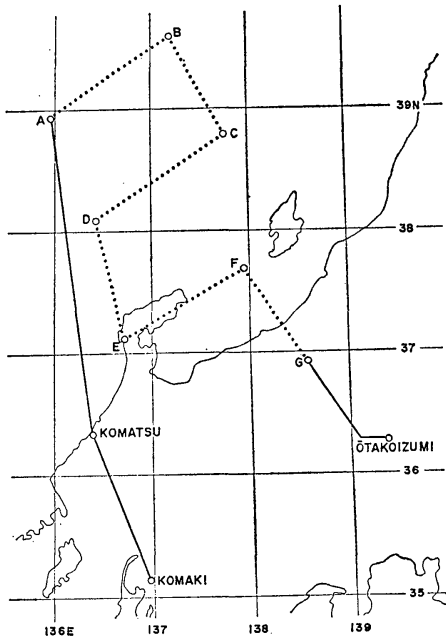

(b) The aerial photographic observation was made along dotted line. colored plexi-glass was used as a filter. The duration of the exposure was $1 / 200$ second and the lens opening was $f / 5.6$ to 8 . The photographs were taken to overlap more than $60 \%$ of the view, since it was required to obtain the topography of clouds.

\section{Synoptic situation}

A remarkable major trough associated with a blocking high had been located quasi-stationarily in the Far East during January 1963. Minor troughs or cold vortices superposed on 


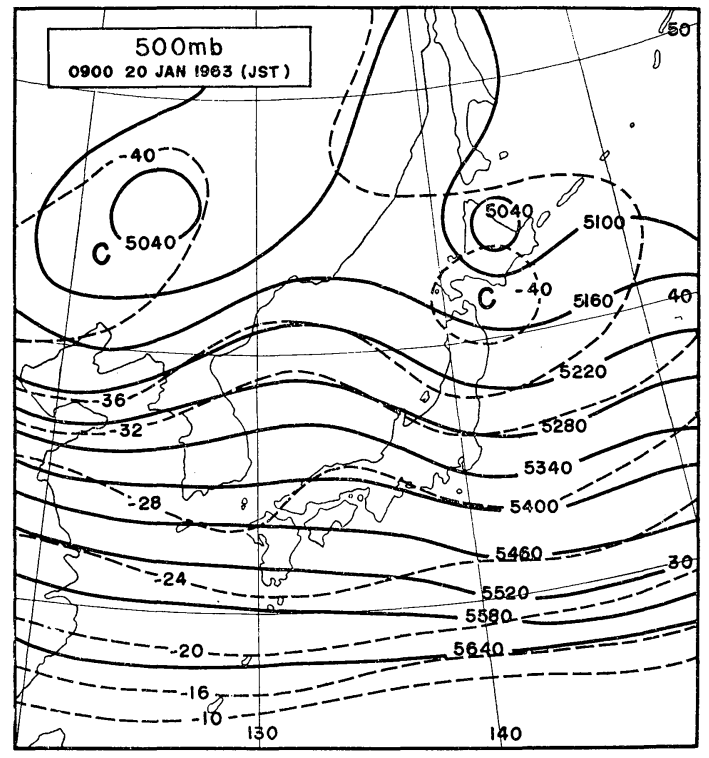

(a)

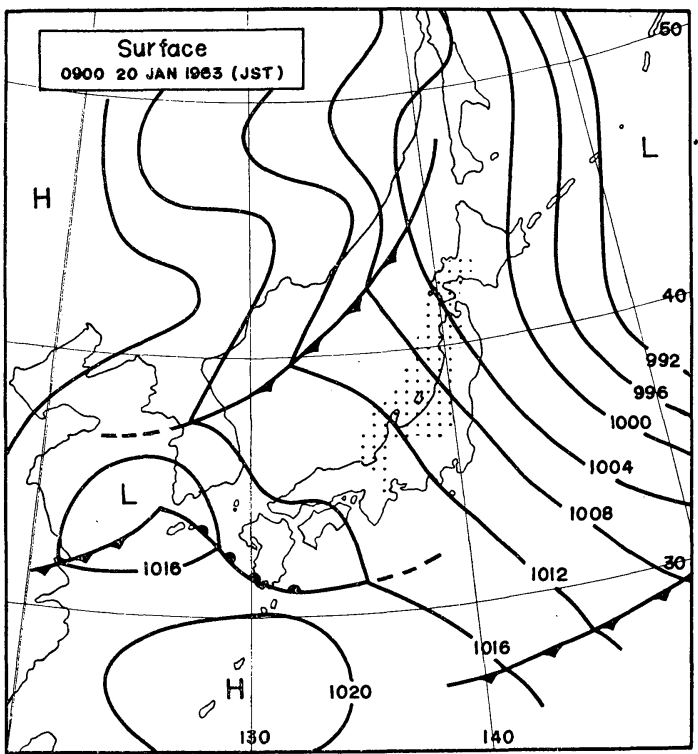

(b)

Fig. 2. $500 \mathrm{mb}$ level (a) and surface (b) weather charts at $0900 \mathrm{JST}, 20$ January 1963 . Solid lines show contours in meter or isobars in $\mathrm{mb}$ and broken lines isotherms in ${ }^{\circ} \mathrm{C}$. Snowfall was observed in stippled area.

it came successively over the Japan Sea southeastward from around Lake Baikal and went away northeastward to the Kurile Islands. The synoptic situation at $0900 \mathrm{JST}$ 20 January is shown in Fig. 2 which consists of $500 \mathrm{mb}$ level and surface weather charts. A minor cold trough which had been over the Japan Sea on the previous day was located over Hokkaido, from which the trough line extended southward along the east coast of the Japan Islands. Another minor cold trough was advancing eastward over the northeast part of China on $500 \mathrm{mb}$ chart. Thus, the Japan Sea was covered by a weak pressure ridge so that it was rather calm and slight snow as a whole in Japan. However, snow shower associated with cumulus and cumulonimbus was observed in Back Japan from south Hokkaido to Wakasa Bay stippled in Fig. 2 (b). According to the report of RECCO of U. S. Air Force, there were observed haze or fog in the west and central part of the Japan Sea and stratocumulus below $1800 \mathrm{~m}$ level and slight altostratus around $5000 \mathrm{~m}$ level in some places. The northwest boundary of the stippled area in Fig. 2 (b) was determined based on RECCO and photographic observation described in the following. Consequently it could be expected that the snowfall in Hokuri-

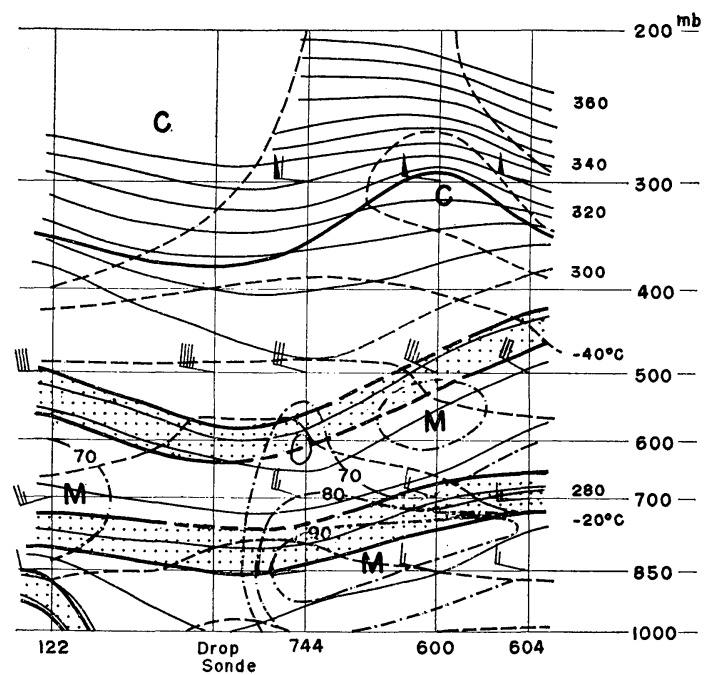

Fig. 3. Vertical cross section at 0900 JST, 20 January 1963. Solid, broken and dash-dotted lines are isentropes, isotherms and isopleths of relative humidity, respectively. Stippled layers show fronts and heavy line tropopause. A short barb of an arrow indicates the wind speed of $5 \mathrm{~m} \mathrm{sec}^{-1}$, a long one $10 \mathrm{~m} \mathrm{sec}^{-1}$ and a pennant $50 \mathrm{~m} \mathrm{sec}^{-1}$. 
$\mathrm{ku}$ District on that day might be due to some causes peculiar to that locality in winter.

Fig. 3 is the vertical cross section at 0900 JST along latitudinal circle from Niigata (47.604) in Japan to Osan (47.122) in Korea including a dropsonde observation by U.S. Air Force which was made at 1300 JST. Two stable layers could be found in this figure. The upper one around $500 \mathrm{mb}$ level was the polar front which accompanied a moist layer corresponding to the observed middle and high clouds of As and Cs. The lower one around $800 \mathrm{mb}$ level corresponded to the front associated with a cold vortex, under which a remarkable moist layer with the relative humidity of more than $90 \%$ was shown. This moist layer in the cold vortex seemed to be the cumulus cloud layer which had a primarily important role on the snowfall. There was found another stable layer lower than $900 \mathrm{mb}$ level only at Osan which was a part of southeast rim of the cold dome over Siberia with

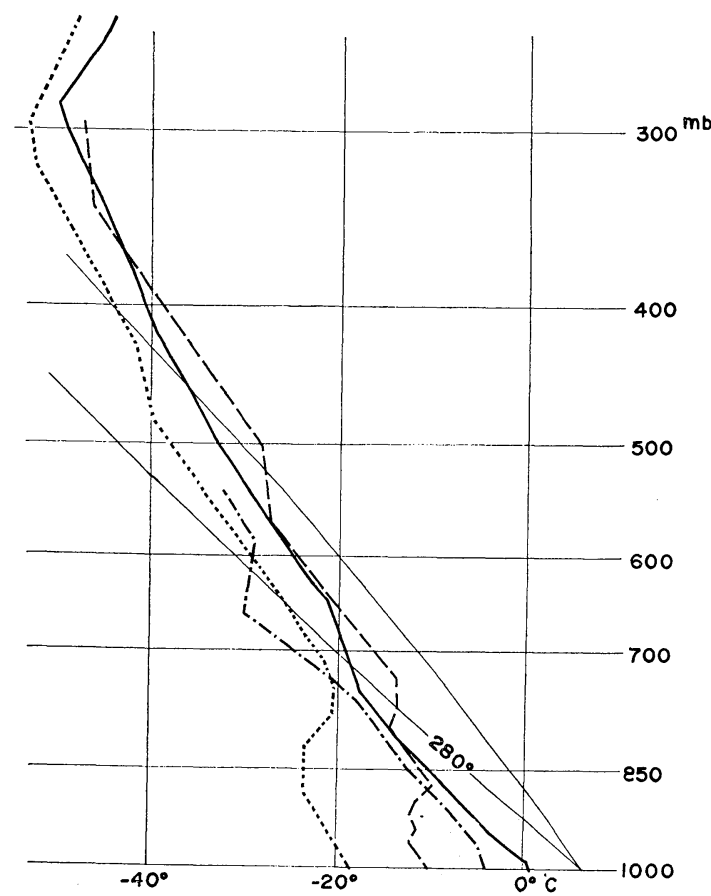

Fig. 4. Radiosonde observations for Wajima (solid), Osan (broken) and Vladivostok (dotted) 0900 JST, 20 January 1963. Dash-dotted line shows the dew-points at Wajima and thin lines are dry and moist adiabats of $280^{\circ} \mathrm{K}$, respectively. a remarkable inversion such as shown by the sounding at Vladivostok (31.960) in Fig. 4.

The detailed analyses of the synoptic situation during the special observation period including that day will be described in another paper (1964).

\section{Photogrammetry}

The present analysis is principally based on the aerial photogrammetry usually used to draw a topographical map. First of all the mosaic picture along the flight path was made by compiling all of 342 photographs taken in the way mentioned in the section 2 . Then, the contours of the upper surfaces of clouds were drawn on it by using the projector called Multiplex which was able to reproduce the geometrically similar disposition of the camera and the clouds to that at the time taking those photographs. However, this method could not take the displacement of every cloud with different velocity into consideration correctly so that some correction should be down. These circumstances are briefly shown in the following.

When a camera is mounted to hold its optical axis vertical in an aircraft at a constant level and the deformation of a cloud is negligible during the time interval of successive shots, $\Delta t$, the following equation can be derived,

$$
h=H-\frac{f \Delta X}{\Delta x}
$$

Here $H$ and $h$ are the heights of the camera (aircraft) and a specified point of the cloud above the sea surface, respectively. $f$ is the focal length of the camera. $\Delta X$, which is expressed in the form, $(U-u) \Delta t$, is the baseline distance referring to the moving cloud. $U$ is the ground speed of the aircraft assumed to be parallel to $x$-axis as shown in Fig. 5 and $u$ is the $x$ component of the velocity of the cloud which is defined to be positive toward the same direction as that of the aircraft. $\Delta x$ is the parallax of the specified point of the cloud on the successive photographs. $P_{1}, Q_{1}, Q_{1}{ }^{\prime}, P_{2}, Q_{2}$ and $Q_{2}^{\prime}$ are the positions of the camera, the specified points of the cloud and their image points on the photographs at time $t$ and $t+\Delta t$, respectively. $\Delta t$ in the present case ranged from 15 to 30 


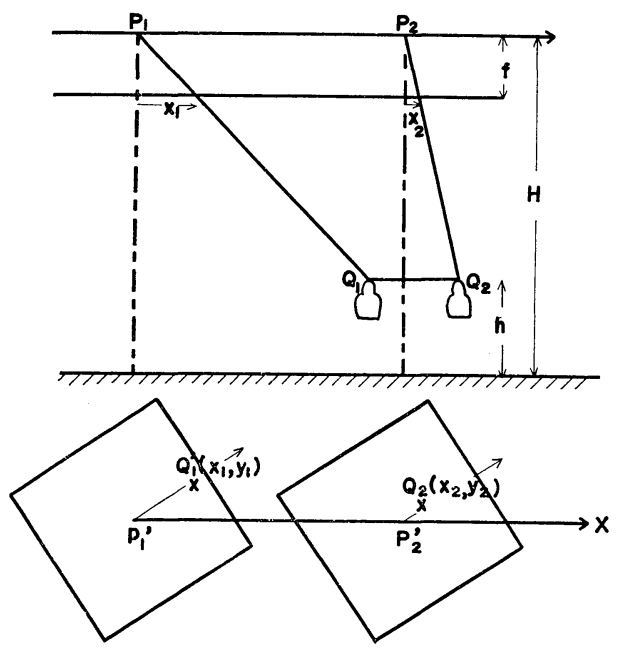

Fig. 5. Geometry of basic aerial photogrammetry.

seconds which depended upon the flight speed and height relative to the cloud to be overlapped more than the prescribed percentage of the view. If the $x$ component of the velocity of the cloud is assumed to be $u^{*}$, the height of the point specified above, $h^{*}$, is estimated as

$$
h^{*}=H-\frac{f\left(U-u^{*}\right) \Delta t}{\Delta x}
$$

The error of the height estimated by eq. (2), $\Delta h$, is expressed as follows,

$$
\Delta h \equiv h^{*}-h=\frac{\Delta u}{U-u^{*}}\left(H-h^{*}\right)
$$

where $\Delta u \equiv u^{*}-u$. The magnitude of the error becomes larger with increasing $\Delta u$ and smaller with increasing $U$. Moreover it is shown by eq. (3) that the overestimation of the displacement of the cloud including the sign leads to the overestimation of its height.

As an example, several photographs including the coast line of Noto Peninsula as well as clouds were used to check the estimation of the cloud height which means the height of the cloud top in the present paper (Fig. 6). When eq. (1) is applied to a point (a) on the coast-line and a point (b) near the mouth of the river, it is reduced to the form,

$$
H=\frac{f U \Delta t}{\Delta x}
$$

Here $U=122 \mathrm{~m} \mathrm{sec}^{-1}, \Delta t=19 \mathrm{sec}, \Delta x=47 \mathrm{~mm}$, $f=152.18 \mathrm{~mm}$. Using these values, $H$ is estimated to be $7505 \mathrm{~m}$ which approximates both $7457 \mathrm{~m}$ obtained by the projector and $7620 \mathrm{~m}$ indicated by the pressure altimeter remained to make some correction. Furthermore, the wind velocity $\left(289^{\circ}, 51.6 \mathrm{~m} \mathrm{sec}^{-1}\right)$ at the flight level estimated from the ground velocity $\left(59^{\circ}\right.$, $\left.122 \mathrm{~m} \mathrm{sec}^{-1}\right)$ and the true air velocity $\left(35^{\circ}\right.$, $97 \mathrm{~m} \mathrm{sec}^{-1}$ ) coincides well with the observed one $\left(281^{\circ}, 50 \mathrm{~m} \mathrm{sec}^{-1}\right)$ on $350 \mathrm{mb}(7745 \mathrm{~m})$ level at Wajima at 1500 JST.

Next, let us estimate the heights of two points (c, d) of the clouds shown in Fig. 6. When the displacements of them are neglected and the flight height is assumed to be $7500 \mathrm{~m}$, their heights are $716 \mathrm{~m}$ and $515 \mathrm{~m}$, respectively. Since $u$ is expected to be $5 \mathrm{~m} \mathrm{sec}^{-1}$, the error of their estimated heights due to the neglection of their displacements, $\Delta h$, becomes about $280 \mathrm{~m}$ which means the underestimation of the height. As is shown in the above discussion, the displacement of the cloud should be taken into consideration in the estimation of its height and the estimated absolute height may inevitably include the maximum error of several hundred meters.

The velocity of the cloud displacement can principally be obtained by its photographs taken from the aircraft flying in the opposite direction each other, although the discussion will be omitted in the present paper.

\section{Cloud distribution along the flight paths}

Here attention will be concentrated in the description of some most characteristic features obtained by the aerial photographic observation, since the general outlook on cloud distribution was made in the article (1963) and many photographs were listed in the report (1963).

\section{1) Characteristic of horizontal distribution}

Aerial photographs were taken along the flight paths $\mathrm{AB}, \mathrm{BC}, \mathrm{CD}, \mathrm{DE}, \mathrm{EF}$ and $\mathrm{FG}$ as indicated in Fig. 1. As a typical example the mosaic picture on $\mathrm{CD}$ course is shown in Fig. 7 of which features are quite similar to those on $\mathrm{AB}$ and $\mathrm{EF}$ courses parallel to $\mathrm{CD}$. The picture is distinctly divided into two parts with great different features each other which are the scattered or broken cumulus clouds in the west and the overcast in the 


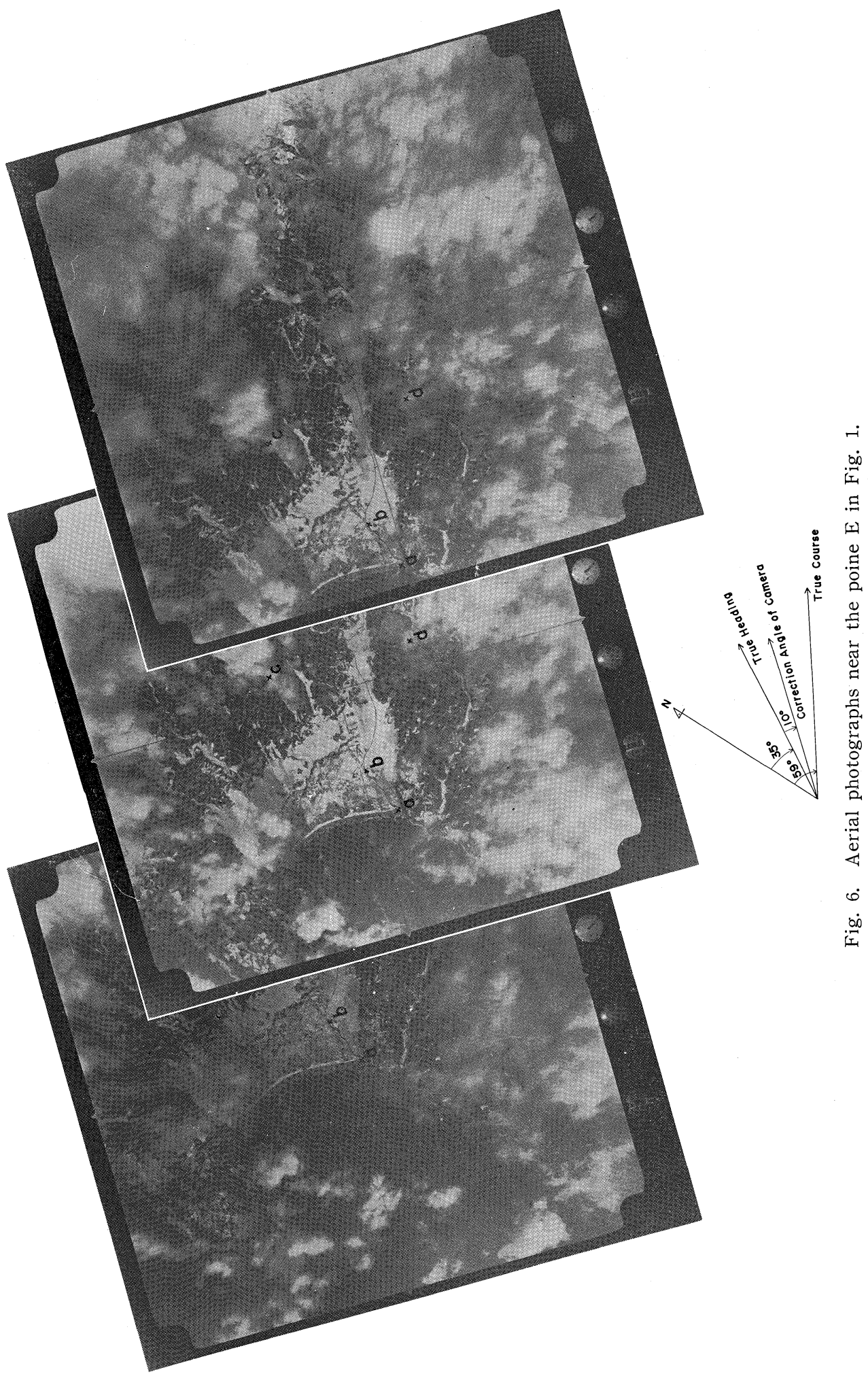



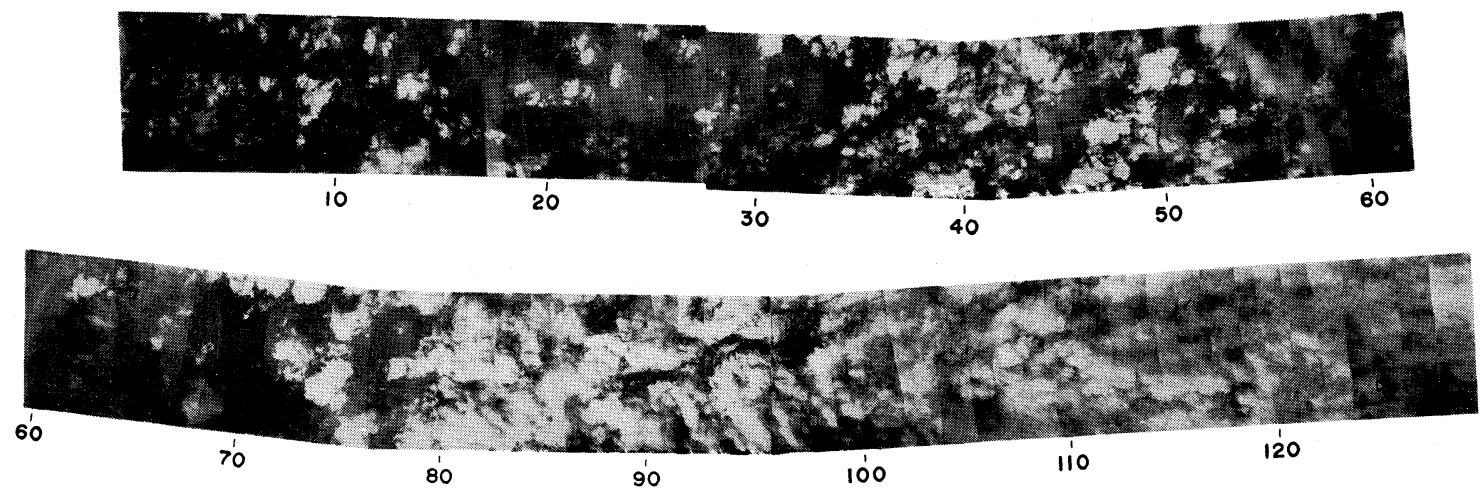

Fig. 7. Mosaic picture of the aerial photographs of the clouds along the flight path

CD. The distance from $\mathrm{D}$ is shown in $\mathrm{km}$ under the picture.

east, respectively.

In the west there are characterized by a great number of cumulus clouds smaller than $1 \mathrm{~km}$ and the wave-like distribution of their groups running meridionally with the wave length of several tens of kilometers. The east part is covered by two cloud layers. The upper thin layer which is obscure on the photographs is of the type of As and Cs at about $5 \mathrm{~km}$ level corresponding to the polar front illustrated in Fig. 3. The lower is dominated by the developed cumulus and/or cumulonimbus clouds which seem to be the same kind of clouds as those in the west found under the lower stable layer in Fig. 3. Fig. 8 shows the contour map of the cloud topography in the region ranging from 30 to $110 \mathrm{~km}$ on CD course. Here it should be noted that the heights of the lower clouds may be underestimated in the presence of both upper and lower clouds, because the projector used here referred to the baseline distance relative to the upper clouds. Roughly speaking the heights of the lower cumulus clouds illustrated in the east of Fig. 8 are estimated lower by 1 to $1.5 \mathrm{~km}$ according to eq. (3). Most of the upper stratiform clouds in the east were thin enough to make the lower one visible through them and were so flat that the contours of them could not be drawn on the map, except for some part around $60 \mathrm{~km}$ from the point D.

Many of the scattered cumulus clouds in the west show the heights of $1 \mathrm{~km}$ or lower and to be likely at the developing stage. Clouds were scarcely observed in the west side of the path from Komatsu to the point
A. Hence the farthermost limit of the cloud cover and the formative region of cumulus clouds may be considered to be fairly near the west of the present observational domain, though the more apparent evidence to show the formative process of cumulus clouds could not be obtained.

On the other hand the east half parts of the courses, $\mathrm{AB}, \mathrm{CD}$ and $\mathrm{EF}$ and whole course of $\mathrm{BC}$ were covered by the stratiform clouds which might consist of upper thin layer and the anvil of cumulonimbus. So the details of cumulus and cumulonimbus clouds expected to be under them could not be observed. However, they might be suggested to be at the developed or matured stage of cumulus clouds reaching around $3 \mathrm{~km}$ level through some portions of thin upper clouds.

\section{2) Distribution of cloudiness}

The cloudiness was tried to be analyzed quantitatively based on the mosaic pictures along the flight paths. As a tendency to arrange the clouds nearly parallel to the northsouth direction could be noticed on them, they were divided into a great number of meridional strips with the width of $1 \mathrm{~km}$ and the cloudiness in each strip which consisted of about 20 squares of $1 \mathrm{~km}$ side was evaluated by counting the squares occupied their areas wider than a half with clouds. Fig. 9 shows the longitudinal distributions of cloudiness along 3 flight paths, $\mathrm{AB}, \mathrm{CD}$ and $\mathrm{EF}$. A part of the path $\mathrm{EF}$ was indicated in broken line, since there was overcast with so thin cloud layer that the earth's surface could be seen and no cumulus cloud could be observed. 


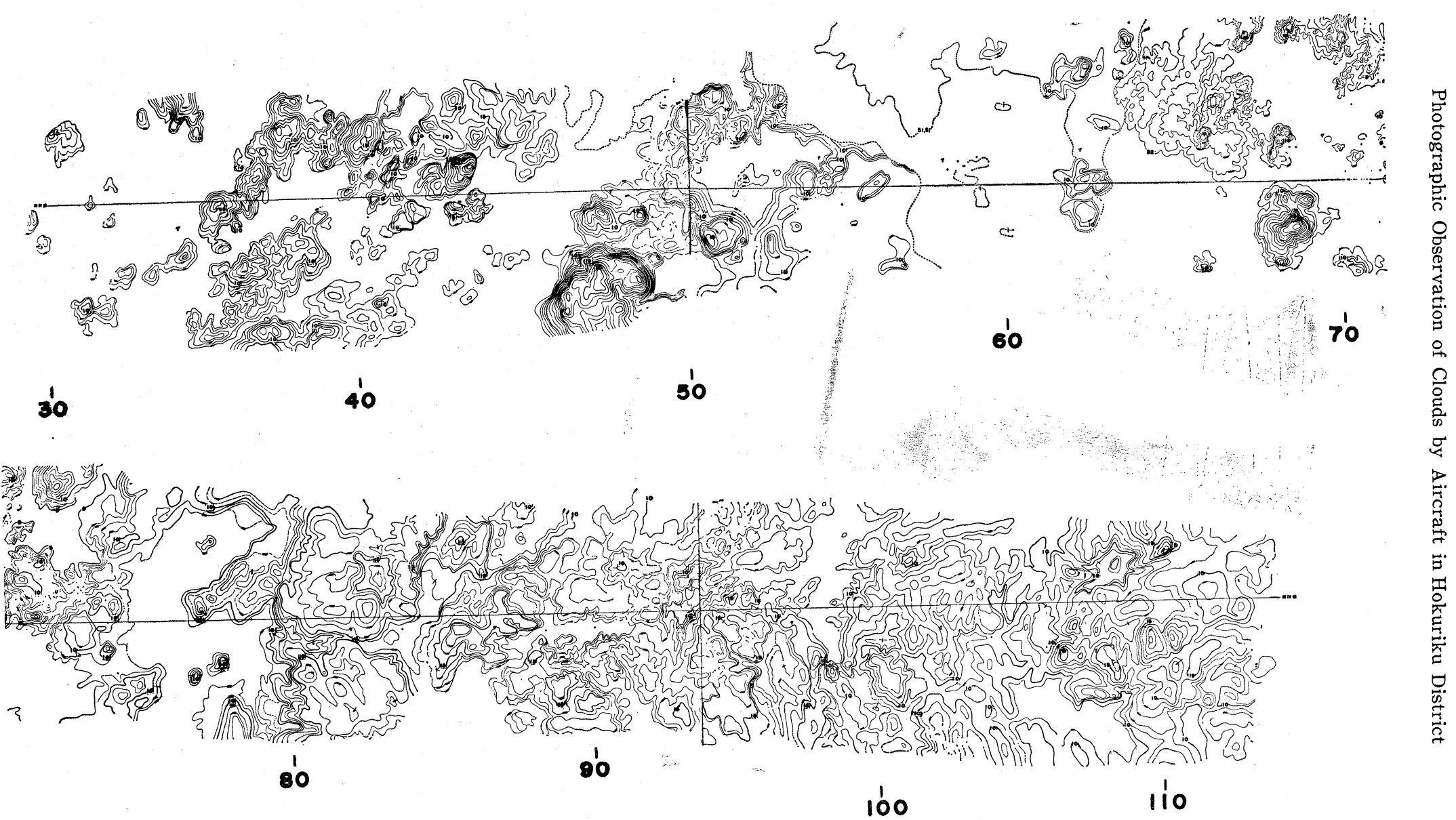

Fig. 8. Contour map of the cloud topography on the path $\mathrm{CD}$ under which the distance from $\mathrm{D}$ is shown in km corresponding to Fig. 7 . Contours are drawn at every $100 \mathrm{~m}$ and labeled in the unit of $100 \mathrm{~m}$. 

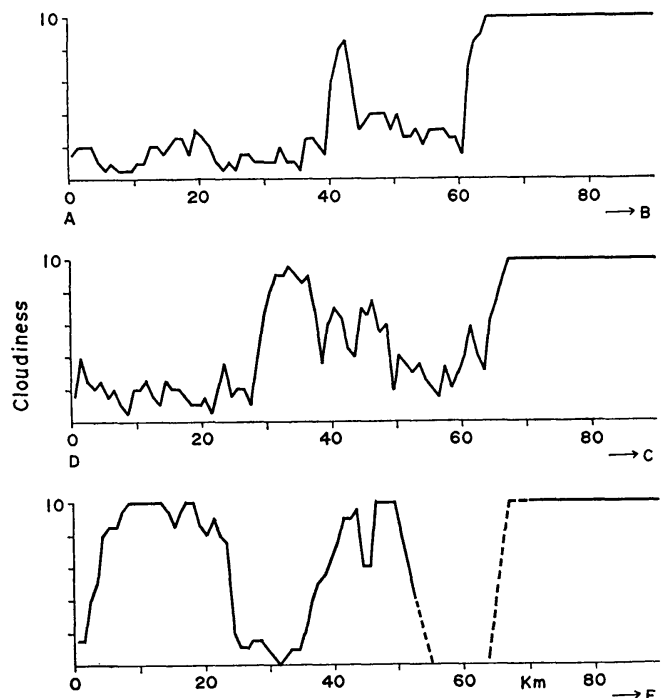

Fig. 9. Longitudinal distribution of the cloudiness on the paths $\mathrm{AB}, \mathrm{CD}$ and EF. The abscissa denotes the distance in $\mathrm{km}$ along each path from $\mathrm{A}, \mathrm{D}$ and $\mathrm{E}$, respectively. The ordinate is the cloudiness indicated in tenths as usual.

The eastern parts of the paths were omitted here because of the overcast quite similar to the east ends shown in Fig. 7.

First of all the cloudiness is characterized by the distribution of the scattered or the broken in the west and the overcast in the east as mentioned before. The increase of the cloudiness toward the east, however, is not monotonical but oscillatory with the wave length of about $30 \mathrm{~km}$. Kuettner (1959) and others indicated the pronounced band structure of the clouds parallel to the general wind with a particular vertical profile of the jet type and Higuchi (1963) also analyzed the same band structure of clouds as Kuettner's one during snow shower period in Hokkaido in Japan. The present case shows the band structure which is not so distinct, nearly perpendicular to the general current without a vertical profile of the jet type.

3) Spectrum of cumulus clouds

The west parts of the paths, $A B$ and $C D$, and the south part of the path, DE, where were characterized by many small isolated cumulus clouds were adopted to investigate the spectral distribution of the sizes and the spacing between clouds. There were observed 460 isolated clouds in the above sample regions. After all of them were replaced by the circles with the same areas as the originals with irregular shapes respectively, their diameters and the distances between the centers of the adjacent clouds were measured. Fig. 10 shows their percentage frequencies in which the spacing is indicated in solid line and the size in broken line. As is shown in

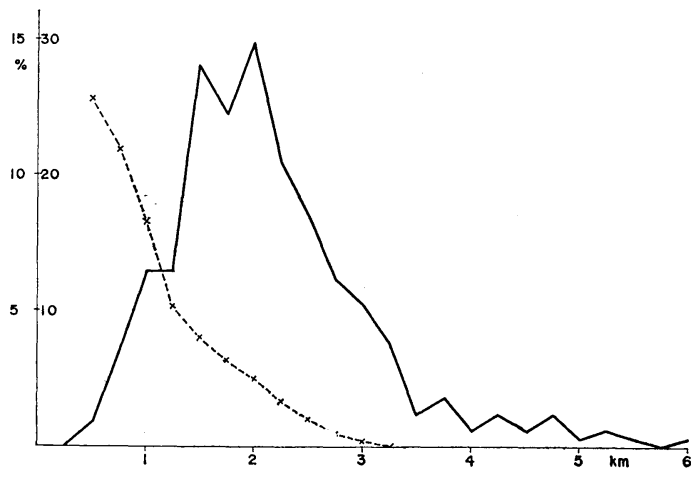

Fig. 10. The frequency distributions of the diameters of the isolated cumulus clouds (broken line) and of the distances between them (solid line). The ordinate denotes the frequency in percentage on the right side for the former and on the left side for the latter. The abscissa shows the length in $\mathrm{km}$.

Fig. 10, the cloud spacings appear most frequently around $2 \mathrm{~km}$. According to the theory of Benard convection by Rayleigh (1916), the ratio of wave length $(L)$ to the thickness $(D)$ of the convective disturbance, $L / D$, is $2^{3 / 2} \fallingdotseq 2.8$ under both upper and lower free boundary conditions. In the case with both rigid boundaries (Jeffreys, 1928), the ratio is about 2.0. If $D$ is assumed to correspond to the height of cloud top and $L$ to the spacing here, these data show to be fairly coincident with those of Benard convection.

On the other hand it is shown that the frequencies of the cloud sizes increase with their decrease in size. Although it was difficult to measure accurately the diameters of the clouds smaller than $250 \mathrm{~m}$ in the present analysis, the maximum frequency could be expected to appear around the diameter of $500 \mathrm{~m}$. If the sky is covered with the clouds which have their diameter $r$ and the distance between them $R$, the cloudiness in percentage $C$ can be 
expressed as follows,

$$
\begin{aligned}
C(\%) & =\frac{\sqrt{3}}{6} \pi\left(\frac{r}{R}\right)^{2} \times 100 \\
& \doteqdot 90.7\left(\frac{r}{R}\right)^{2}
\end{aligned}
$$

When $r$ is assumed to be $500 \mathrm{~m}$ and $R 2000 \mathrm{~m}$, then $C$ is $5.67 \%$. Malkus and et al. (1961) showed that the rain area in the hurricane Daisy in 1958 was occupied only by $4 \%$ of cumulonimbus based on the aerial photographic observation. Thus it seems that the active cores of cumulus convection in the atmosphere occupy only several percents of the domain associated with convective activity. Since a cumulus convection behaves as a prominent element transporting sensible heat and water vapor, a group of cumuli may modify effectively the larger scale atmospheric state controlling them. So the study of the spectrum of cumulus cioud should be promoted as well as that of an individual character.

\section{Summary and remarks}

The main features of the observation may be summarized as follows:

1) Cumulus clouds were already formed over the Japan Sea $200-300 \mathrm{~km}$ off the coast of Hokuriku District, though the farthest origin of cumulus clouds over the Japan Sea off Back Japan could not be ascertained at the present observation. It may be suggested that the supply of sensible heat and water vapor from the sea has an important role on the formation of cumulus clouds through destabilizing the lower atmospheric layer, because the forced ascending motion due to both topographical and dynamical effects was not feasible to expect.

2) To the northwest of Noto Peninsula there were dominated by scattered small cumuli lower than $1 \mathrm{~km}$ level which had the maximum frequency in the horizontal scale of several hundred meters and in the spacing of $2 \mathrm{~km}$.

3) The cloudiness increased eastward along the flight paths and its change was not always monotonical but oscillatory. Hence the distribution of the cloudiness showed nearly meridional band structure with the interval of about $30 \mathrm{~km}$ perpendicular to the general wind.

4) The stratiform clouds which might be incudes spreading from the upper portion of cumulonimbi predominating in the half eastern part of the present observational domain were observed. Furthermore, upper thin cloud sheet consisting As or Cs and somewhere Ac were found around $5 \mathrm{~km}$ level. Therefore no detail of individual cumulus or cumulonimbus clouds could be well observed. Some of them, however, exposed their tops with flower cabbagelike figure which showed to be at the matured stage of their life cycle. They reached near $3 \mathrm{~km}$ level and had larger horizontal scale than those in the west.

5) The horizontal distribution of clouds west to east revealed the successive stages of the life cycle of cumulus convection from the formative stage to the matured.

The present observation by aircraft could be performed over only a small region of the Japan Sea and not on a typical day during severe snowfall period mainly because of a restricted capability of the aircraft available for us. Then, the oblique photography as well as the vertical one is recommended to be used to compensate the serious limit of climbing power and navigation range of the aircraft. In order to throw light on the mechanism of cumulus convection shown here, the measurement of meteorological elements such as temperature and water vapor should be made together with the photographic observation. In addition to the dynamical investigation the cloud physical process may provide another important aspect to be taken into consideration on heavy snowfall.

\section{Acknowledgement}

The author wishes to express his hearty thanks to Dr. H. Arakawa and Dr. S. Matsumoto for their guidance and encouragement throughout this work. He is also much obliged to members of Heavy Snowfall Research Group in his laboratory, without whose help this work could not have been completed.

The author is indebted to Higashi Nihon Kōkū K. K., especially navigator, Mr. M. Takahashi and photographer, Mr. S. Shibazaki for their sacrificial cooperation. He acknowledges with deep gratitude the assistance 
provided by Niigata Airport Preservation Office, Niigata Local Meteorological Observatory, Tokyo International Airport Aviation Weather Service and Nagoya Airport Aviation Weather Station to secure their navigation.

$\mathrm{He}$ is also indebted to Miss. $\mathrm{H}$. Imai for drawing figures and to Mrs. Y. Tsuneoka for typewriting the manuscript.

\section{References}

Higuchi, K., 1963: The band structure of snowfalls. Journ. Met. Soc. Japan, Ser. II, 41, 53-70. Jeffreys, H., 1928: Some cases of instability in fluid motion. Proc. Roy. Soc., 118, 195-208.
Kuettner, J., 1959: The band structure of the atmosphere. Tellus, 11, 267-294.

Malkus, J. S., C. Ronne and M. Chaffee, 1961: Cloud patterns in Hurricane Daisy, 1958. Tellus, 13, 8-30.

Matsumoto, S. and T. Asai, 1963: Aerial photographic observation of clouds during snowfall period-Preliminary report. Tenki, 10, 50-51. (in Japanese)

Matsumoto, S., et al., 1964: Analytical study of the cold vortices during heavy snowfall period in 1963. To be published.

Rayleigh, L., 1916: On convective currents in a horizontal layer of fluid when the higher temperature is on the under side. Phil. Mag., 32, 529-546.

\title{
北陸地方降雪期における雲の航空写真観測
}

\author{
浅 井富 雄 \\ (気象 研 究 所)
}

北陸地方飞括ける豪雪機構研究のため飞 1963 年 1 月 16 日から 25 日までの 10 日間, 臨時観測が行なわれた。 その一環として上記期間中の 20 日飞雲の航空写真観測を行なった。北陸地方沖の日本海上飞晾ける雲の水平分布や 高度分布が約 $8 \mathrm{~km}$ の高度から撮られた水平航空写真に基づいて得られた。日本海上飞和ける積雲の発生限界を確か めることは出来なかったが，北陸沿岸沖 $200 \sim 300 \mathrm{~km}$ 付近は積雲発生域に近いものと推定される。

能登半島北西海上では, 高度 $1 \mathrm{~km}$ 以下, 水平規模数 $100 \mathrm{~m}$ の小規模な積雲が散在する。北陸沿岸飞近づく飞従 って積雲の規模は次第に大きくなり高度も $2 \sim 3 \mathrm{~km}$ 飞達し, 成熟した積乱雲の様相を呈する。この分布变化は連続的 というよりはむしろ波状である。観測域の東半部は層状雲にっおわれていた。日本海上で形成された積雲が北陸地 方で有効に降雪として解放されることが示唆される。 